\title{
PROSPECTS FOR SERVICE SECTOR EMPLOYMENT GROWTH IN NON-METROPOLITAN AMERICA
}

\author{
James P. Miller and Herman Bluestone*
}

\section{Introduction}

Service-producing industries have provided most of the employment growth in non-metropolitan America and all of it in metropolitan America since 1969. Growth in both kinds of areas appears to be largely explained by changes in demography, household incomes, consumer tastes, and technology. Service industry growth also tends to be linked to growth in goods production. That linkage appears to be stronger for non-metropolitan areas than for metropolitan areas partly because the goods-producing sector is a larger employer in non-metropolitan areas and because non-metropolitan areas appear to lack the amenities needed to attract business-oriented services such as data processing, insurance, brokers, and other administrative services. Preliminary analysis of recent employment trends suggests that non-metropolitan areas may continue to lag behind metropolitan areas in services unless they can capture a larger share of the nation's goods production or can expand export services.

Goods-producing employment has been stagnant in the past 15 years and manufacturing has stopped decentralizing from non-metropolitan to metropolitan areas. Therefore, future employment growth prospects for nonmetropolitan areas may hinge on their ability to compete with metropolitan areas for service sector jobs. Employment growth in goods-producing industries (manufacturing, construction, mining, agriculture, forestry, and fisheries) has been arrested partly by continuing gains in labor productivity and, more recently, by more intense foreign competition. Nearly all of the employment increase has been in the service-producing industries (wholesale and retail trade, finance, insurance, real estate, other private services, and government).

This paper focuses on how successfully non-metropolitan areas can compete for service-producing industry. Data on wage and salary employment for the 1969-84 period are used to assess how well non-metropolitan areas have been keeping up with metropolitan areas in expanding service jobs. Changes in patterns of employment growth in non-metropolitan and metropolitan service industries between 1969-76 and 1976-84 are described and

\footnotetext{
*James Miller and Herman Bluestone are economists in the Agriculture and Rural Economy Division, ERS, U.S. Department of Agriculture.
}

these changes related to the growth pattern in goodsproducing industries. In addition, data are used to identify the types of service activities that have concentrated in non-metropolitan areas.

\section{The Process of Service Sector Growth}

Classical export base theory predicts that an area's employment in non-basic industries (those serving local markets) will expand to complement growth in its basic industries (those serving markets outside the area) (North, 1955). Basic industries generally tend to be goodsproducing industries and non-basic industries tend to be service industries. Thus, data for these two categories of industries have often been used to "test" the export base model. Employment trends over the last 25 years indicate, interestingly, that service sector employment increased dramatically despite little growth in the goods sector. Because of this growth difference, goods-producing employment at the national level declined fairly steadily from about 41 percent of total non-farm wage and salary employment in 1950 to about 26 percent in 1985 . If we consider the United States as a region exporting to the rest of the world, export base theory cannot explain the expansion of service employment over this entire period, because employment in the goods-producing industries did not increase a great deal.

Others have argued that the national trend in service sector employment growth has been much more affected by changes in household income, technology, and consumer tastes than by changes in employment in basic or export industries. For example, Fuchs offers three hypotheses to explain the service sector employment growth (1968). First, he postulates that since services have an income elasticity of demand greater than one, services per capita would increase faster than income as per capita income rises. Given the substantial increase in real per capita income in the United States over the last quarter century, we might expect services to account for an expanded share of both national income and employment for this reason alone. Second, Fuchs suggests that as the economy grows, it becomes more efficient for some services, once provided within the firm and household, to be procured from outside. Services provided by management, consulting, public relations, and data processing 
firms are examples of those being contracted out by firms, while day care, restaturant dining, and household help are those being used by households. In many cases, the same volume of services is being provided as before, yet these services are now measured as a separate market activity and counted as part of the service sector. Specialization, however, particularly in metropolitan centers, has lowered the cost of many outside services and actually increased the volume demanded and produced. Finally, Fuchs seeks to explain the increasing importance of services in the national economy by noting that growth in labor productivity has been slower in the service-producing industries than in agriculture, manufacturing, and mining. Thus, even if the output of services increases no faster than the output of goods, employment would increase more rapidly in service-producing industries than in goodsproducing industries. As a result, the share of total employment in services would increase.

The relatively fast growth of service employment has also been attributed to the aging of the United States population. The premise is that older people spend a larger share of their income on services than do younger people.

The export base theory, which was not intended to explain service sector growth at the national level, is expected to perform better at the regional level, particularly in regions that have experienced rapid change in their basic sector and that specialize in goods production, such as agricultural, mining, and manufacturing areas. Hence, this theory might be expected to be relevant for explaining service sector employment growth in non-metropolitan and metropolitan areas. For example, Garnick (1984, 1985) explains non-metropolitan employment growth in the 1970s in the context of the export base model. Service employment expanded to complement the growth of basic goods production. It was, according to Garnick, a process of "catching up" with the rapid expansion of basic industries. Manufacturing industries, in search of low wages and non-union labor, had expanded rapidly. Agriculture and related industries, with the promise of more Russian wheat sales, expanded also, as did many recreation- and retirement-related industries. Garnick, however, expresses concern about the recent trend of service employment in non-metropolitan areas which, he observes, has slowed and "may be close to peaking." Factors favoring rapid employment growth in the 1970 s may have spent their force in the 1980s. Markets for traditional agricultural and energy-related products have not expanded as rapidly, and foreign competition in low-wage manufacturing has increased.

Bender (1987) provides further support for the export base explanation of growth in nonmetropolitan areas. He concludes that services should be considered as playing a "passive role" in non-metropolitan county growth. Growth in the service sector is ultimately dependent on the expansion of basic goods production and other sources of income from outside the county, such as transfer payments, Bender asserts.

\section{Locational Orientation of Services}

Location theory suggests that consumer services, such as retail stores, restaurants, and auto repair shops, will be distributed in relation to population, whereas "advanced" producer services, such as data processing and other business services which can market over large areas, will tend to locate in metropolitan areas (Daniels, 1985). These advanced services will be confined largely to metropolitan areas because of the cost and marketing advantages of agglomeration. ${ }^{1}$ Such agglomeration will leave the peripheral, non-metropolitan areas with "residual specialization" in certain consumer services of the kind provided by government, recreational, and retirement businesses and some distributive activities. Some examples of residual specialization in these services would include warehousing, trucking firms, motels, and restaurants at non-metropolitan interstate highway interchanges.

Duncan (1959) demonstrated that a certain city size is required to support particular service industries. News syndicates and miscellaneous advertising, for example, required a critical city size of at least 50,000 to 100,000 persons in 1954. Business services, in general, are more urbanized than personal services, and the most specialized consumer services also tend to be metropolitan-oriented. The least specialized services tend to be non-metropolitan-oriented, such as repair shops run by jacks-of-alltrades or offices that offer a combination of real estate, insurance, and financial services.

Noyelle (1983) argues that advanced producer services, which have recently contributed more to national employment and GNP growth than other services, will continue to locate and expand only in the largest cities. Advanced producer activities provide a multitude of business services (data processing, insurance, brokerage, and other administrative services) to other metropolitan businesses. These activities either market directly to other businesses outside the metropolitan areas or sell to local businesses who then export goods that embody these services (Beyers and Alvine, 1985). Noyelle believes that a "functional dichotomy" has emerged between a few major metropolitan areas that are well-positioned to produce and export advanced services and other, smaller metropolitan and non-metropolitan areas. Consequently, most non-metropolitan areas are not expected to attract 
advanced producer activities.

Cocheba, Gilmer, and Mack $(1985,1986)$ lend further support to Noyelle's findings by documenting the weakness of advanced producer services in the predominantly non-metropolitan Tennessee Valley. They attribute the relatively slow growth of the area's service sector to (1) low per capita income, which has inhibited the growth of many consumer services, and (2) the low proportion of company headquarters in the region, which has reduced the need for producer services. Growth of manufacturing in the Tennessee Valley has been primarily in branch plants controlled by headquarters in other regions. The three researchers concluded that the absence of headquarters in the region has limited the growth of legal, engineering, accounting, and other support services that typically locate in or near headquarters' operations. These findings suggest that reliance on indigenous non-metropolitan economic development through the creation and expansion of new locally-owned businesses may be more effective than attracting branch plants of regional or national firms.

While most non-metropolitan areas appear less favorably placed than metropolitan areas to participate in the current rapid expansion of advanced producer services, the outlook for total employment growth in the nonmetropolitan service sector has some bright aspects. First, residential services have been increasing about as fast in non-metropolitan as in metropolitan areas. Second, some non-metropolitan areas have experienced success in exporting services. For example, a survey of 385 nonmanufacturing businesses in non-metropolitan areas of Wisconsin found a significant amount of exporting activity (Smith, 1984; Smith and Pulver, 1981). The exporting businesses were typically absentee-owned businesses that chose nonmetropolitan locations because of labor and other cost advantages. Some 27 percent of the businesses studied made over half of their sales outside the local area.

Non-metropolitan areas may eventually benefit from the rapid improvement of information technology, telecommunications, satellite transmission, and personal computers. In the future, some advanced export services may be provided via telecommunication from locations outside of metropolitan areas. The location decision may be characterized as a "telecommunications/transportation trade-off." This trade-off is an expression of the extent to which information using telecommunications can provide an alternative to the physical movement of people, goods, and information. Garnick (1984) argues that technological change favors a dispersion of both production activities and producer services. He maintains that advances in telecommunications and transportation have overcome the barriers of distance and reduced the importance of agglomeration economies in the provision of producer services. Noyelle (1983) also suggests that data processing facilities of large businesses (notably in insurance and banking) may increasingly be attracted to non-metropolitan locations because advances in communications allow them to operate at a distance from the central office, and advances in data processing permit the employment of relatively low-skilled easily available clerical labor.

Leven (1985) agrees that the new information technology can decentralize producer services, particularly information control functions formerly carried out by middle managers and staff within the firm. Daniels (1985), however, is less certain about the "pace and outcome" of the possible spatial changes to result from innovations in computer and telecommunications technology. "Speculation seems to predominate over fact," he observes. The same technology that could promote decentralization of some service industries could also lead to centralization of others. Daniels indicates that lower order consumer services could continue to disperse and become increasingly localized whereas higher order producer services, mainly concerned with control rather than customer service, could become even more centralized.

Most of the more desirable service jobs will be in metropolitan areas, according to recent studies. Managerial, professional, and technical jobs that pay well are not generally found at non-metropolitan service locations. They are found in metropolitan centers where company headquarters, regional offices, and specialized service activities tend to concentrate. Lower order service activities that rely on unskilled labor, notably sole proprietorships and branch outlets in retailing and other residentiary services, are commonly found in non-metropolitan areas. Metropolitan-oriented services-distributive, producer, and social-ranked higher than consumer services in average annual earnings in 1975 , according to a study by Stanback and Noyelle (1982).

\section{Approach Used in Data Analysis}

Our empirical analysis differs from earlier work on the service industries in three ways: it uses a more comprehensive database; it is national, rather than regional in scope; and, it focuses on differences between the non-metropolitan and metropolitan service sectors. ${ }^{2} \mathrm{We}$ use wage and salary employment data from the U.S. Department of Commerce (Bureau of Economic Analysis) to compare metropolitan/nonmetropolitan changes in the rates of employment growth and to quantify differences in the distribution of employment among various service industries. Changes of growth in these industries in non-metropolitan areas, both adjacent and not adjacent 
to metropolitan areas, are also examined.

Patterns of employment change between 1969-76 and 1976-84 are measured by compounded average annual growth rates. The early period was one of rapid manufacturing employment growth in non-metropolitan areas and decline in metropolitan areas. The most recent period was one of relatively slow non-metropolitan growth. We hypothesized that the more rapid growth in non-metropolitan basic industries in the earlier period would cause employment in the non-metropolitan service sectors to increase at a faster pace than in the metropolitan areas. And, conversely, the relatively slower non-metropolitan basic sector growth in the later period would cause the non-metropolitan areas to lag behind the metropolitan areas in service employment growth.

We used employment location quotients (discussed in more detail later) to identify the kinds of areas where various categories of service-producing industries tend to concentrate. A location quotient greater than one shows that a group of counties, such as large metropolitan areas or non-metropolitan counties not adjacent to metropolitan areas, tend to specialize in a particular service-producing category and to market (export) some of the service outside the area. ${ }^{3}$ Quotients less than one suggest that the industry is underrepresented in the county group and imports the service.

We lack sufficient detail in census data and in data based on administrative records of government programs to examine employment in the service industry as rigorously at the county level as we would like. Like others, we have followed the conventional approach of classifying services as everything other than extractive industries (agriculture, mining, forestry, fisheries) and transformative industries (manufacturing and construction) (Stanback, 1979; Stanback and Noyelle, 1982). We have grouped service-producing industries into five categories by type of consumption (or market), a modification of a classification first developed by Singlemann (1979). The five industry groups are consumer services, social services, government, producer services, and distributive services. The two-digit Standard Industrial Classification service industries included in each group are shown in Appendix Table 1. The major market for producer services, by definition, is other businesses. The output of distributive services (transportation, public utilities, and wholesale trade) also is linked closely to the output of other businesses. The market for consumer services is private households. The demand for social services depends on both private and government expenditures. And finally, the level of government employment depends on the political process. This system helps us describe how growth and employment shares in highly aggregated serv- ice categories which exhibit common locational patterns according to the level of urbanization.

\section{Recent Growth in the Service Sectors}

Employment in the service industries increased rapidly in both non-metropolitan and metropolitan areas from 1969-84. Much of this growth appears to be associated with changes in demography, household income, consumer tastes, and technology. Part of the change in the rate of service employment growth in both non-metropolitan and metropolitan areas between the first and second halves of the 1969-84 period is associated with changes in the rate of goods-producing employment growth. However, the service industry appears to have more of a life of its own in metropolitan areas. Employment in new urbanbased service activities (producer services) continued to expand and even to accelerate after 1976, partly because most of the newly created services, especially those based on recent advances in technology, have been originating in metropolitan areas and have been slow to decentralize to non-metropolitan areas.

Employment grew faster in non-metropolitan than metropolitan areas in 1969-76 (Table 1). Non-metropolitan expansion of employment in goods production, at an annual 1.4 percent, was complemented by a 2.5 percent annual growth of employment in service industries. On the other hand, even though metropolitan employment in goods production declined at an annual rate of 1.1 percent, employment in metropolitan service industries areas continued to expand at an annual rate of 2.2 percent.

Driven by rapid growth of the goods-producing industries, employment in business and consumer services expanded rapidly in non-metropolitan areas between 1969 and 1976. Employment in producer, distributive, and social services expanded at a faster annual rate in nonmetropolitan than metropolitan areas. The rate of service employment expansion was even faster in non-adjacent non-metropolitan areas (Table 2) where employment in goods production, particularly in extractive industries, also grew at a fast pace. Employment in consumer services and government increased at about the same rate in non-metropolitan and metropolitan areas.

After 1976, employment grew slower in non-metropolitan areas compared with metropolitan areas. Nonmetropolitan employment growth in goods production came to a virtual halt between 1976 and 1984, with the average annual growth rate declining by 1.3 percentage points from the 1969-76 rate. In service industries, the reduction in the growth rate was only half as large, but, even so, it was almost one percentage point lower than the metropolitan rate. Non-metropolitan growth rate reduc- 
Table 1

Change in Non-farm Wage and Salary Employment in Goods- and Service-producing Industries

Metropolitan and Non-metropolitan Counties, 1969-84*

\begin{tabular}{|c|c|c|c|c|c|c|c|c|}
\hline \multirow{4}{*}{$\begin{array}{l}\text { County Type and } \\
\text { Industry Group }\end{array}$} & \multirow{4}{*}{$\begin{array}{l}\text { Number } \\
\text { Employed } \\
\text { in } 1969 \\
\text { (millions) }\end{array}$} & \multicolumn{4}{|c|}{ Change in Employment } & & & \\
\hline & & \multicolumn{2}{|c|}{$1969-76$} & \multicolumn{2}{|c|}{$1976-84$} & \multirow{2}{*}{\multicolumn{3}{|c|}{ Share of Employment (percent) }} \\
\hline & & Number & Rate & Number & Rate & & & \\
\hline & & (millions) & (percent) & (millions) & (percent) & $\overline{1969}$ & 1976 & 1984 \\
\hline \multicolumn{9}{|l|}{ United States } \\
\hline Goods-producing & 25.8 & -0.9 & -0.5 & 1.1 & 0.5 & 32.9 & 28.8 & 25.7 \\
\hline Service-producing & 52.6 & 8.7 & 2.2 & 13.8 & 2.6 & 67.1 & 71.2 & 74.3 \\
\hline Total & 78.4 & 7.8 & 1.4 & 14.9 & 2.0 & 100.0 & 100.0 & 100.0 \\
\hline \multicolumn{9}{|l|}{ Metropolitan } \\
\hline Goods-producing & 20.2 & -1.5 & -1.1 & 1.0 & 0.7 & 31.8 & 27.1 & 24.1 \\
\hline Service-producing & 43.4 & 7.0 & 2.2 & 12.0 & 2.7 & 68.2 & 72.9 & 75.9 \\
\hline Total & 63.7 & 5.5 & 1.2 & 13.1 & 2.2 & 100.0 & 100.0 & 100.0 \\
\hline \multicolumn{9}{|l|}{ Non-metropolitan } \\
\hline Goods-producing & 5.5 & 0.6 & 1.4 & 0.0 & 0.1 & 37.4 & 35.8 & 32.5 \\
\hline Service-producing & 9.2 & 1.7 & 2.5 & 1.8 & 1.9 & 62.6 & 64.2 & 67.5 \\
\hline Total & 14.7 & 2.3 & 2.1 & 1.8 & 1.3 & 100.0 & 100.0 & 100.0 \\
\hline
\end{tabular}

*Metropolitan counties are those which were in Metropolitan Statistical Areas designated by the Office of Management and Budget as of 1983. All other counties are non-metropolitan. Rates of change are compounded annual rates. Detail on employment may not add exactly to totals due to rounding.

Source: Compiled from county data provided by the Bureau of Economic Analysis, U.S. Department of Commerce. 
Table 2

Rates of Change (percent) in Non-farm Wage and Salary Employment, Selected Groups of Industries

Metropolitan and Non-metropolitan Counties, 1969-76 and 1976-84*

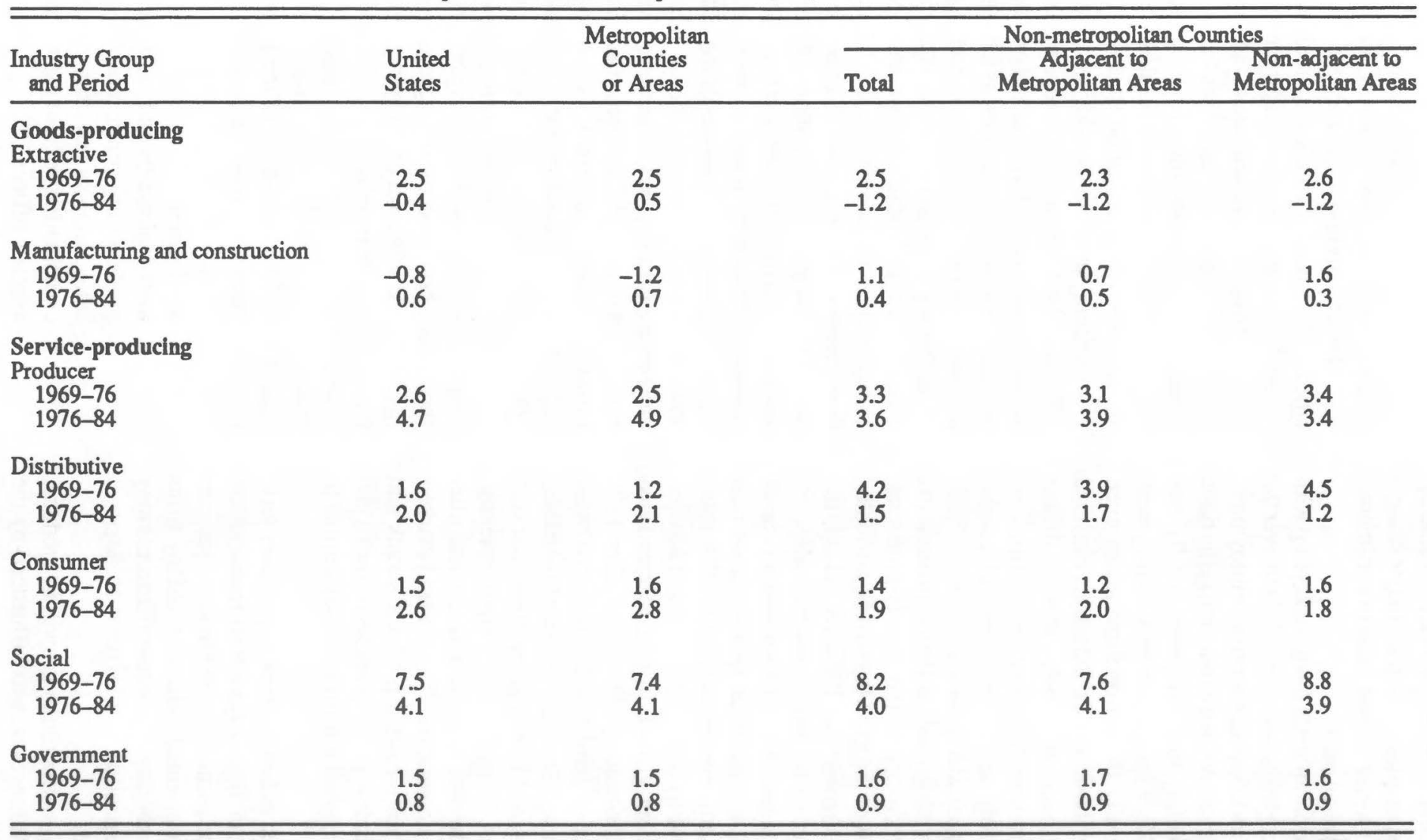

*Metropolitan counties are those which were in Metropolitan Statistical Areas designated by the Office of Management and Budget as of 1983. All other counties are non-metropolitan. Rates of change are compounded annual rates. The two-digit SIC industries included in each industry group are shown in Appendix Table 1.

Source: Compiled from county data provided by the Bureau of Economic Analysis, U.S. Department of Commerce. 
tions of 4.2 percentage points in social services, 2.7 percentage points in distributive services, and 0.7 percentage point in government more than offset growth rate increases in producer and consumer services (Table 2). Except for government, employment in all major categories of services grew at lower annual rates in non-metropolitan than in metropolitan areas.

Thus, non-metropolitan areas have not kept up with metropolitan areas in service employment growth over the 1969-84 period. Non-metropolitan service employment, corresponding closely to the pace of expansion in the basic or goods-producing sector, first expanded rapidly and then slowed in 1969-84. However, service employment continued to grow rapidly in metropolitan areas, even though employment in basic goods industries declined during 1969-76 and increased only slowly during 1976-84. Growth in non-metropolitan services appears to have been linked closely to the expansion of goodsproducing industries, particularly during the early 1970s. By contrast, while service growth in metropolitan areas did benefit from the recovery of the goods-producing sector after 1976, much of the growth must be attributed to other factors. Throughout the 1969-84 period, the metropolitan service sector tended to take off independently of the basic goods sector and set its own course of rapid growth. The non-metropolitan service sector may eventually follow the same course, but, since 1976, it has fallen behind the pace of metropolitan service industries.

Slower employment growth in producer and distributive services in non-metropolitan areas after 1976 reflects the reduced rate of growth in the traditional nonmetropolitan export base. Services provided by banks, realtors, trucking firms, and warehousing firms that supported rapid expansion in agricultural, manufacturing, and energy-related industries were less in demand after 1976. This slackening demand resulted as world markets for agricultural and energy-related products shrank and non-metropolitan areas lost their competitive locational advantage in low-wage, labor-intensive manufacturing to foreign countries.

More rapid growth of employment in producer services in non-metropolitan areas adjacent to metropolitan areas after 1976 may be related, in part, to the expansion of metropolitan export-oriented industries. Many firms that provided producer services in metropolitan areas may have relocated and expanded employment in adjacent non-metropolitan areas.

Much of the non-metropolitan growth in producer and consumer services, however, was influenced by the growth in residential and local business demand which had been steadily building in the 1970s. These services expanded primarily to catch up with the requirements of a growing population and workforce.

\section{Location of Services in 1984}

The shift from goods to services has had a major effect on metropolitan economies. Unlike goods production, service activities have tended to concentrate in large cities. As shown by location quotients greater than one (Table 3), three of the five major categories of services (producer, distributive, and social) are concentrated in the largest metropolitan areas. Smaller metropolitan areas appeared to be less specialized in these broad categories of services. The location quotients decline to less than one as the level of urbanization declines from the largest metropolitan areas to non-adjacent, non-metropolitan counties. The location pattern reverses for goods production and government, however, to favor non-metropolitan counties. Extractive industries, as expected, were clearly dominant in non-adjacent, non-metropolitan counties. Manufacturing industries were concentrated in small metropolitan and adjacent non-metropolitan counties. Government also seems to have a larger presence away from metropolitan areas, but this may be a misinterpretation of the employment location quotient. The employment location quotient may overstate the importance of government services in non-metropolitan areas because there are significant economies of scale in the provision of some government services, which means that it takes more employees to provide the same level of services per capita than in metropolitan areas (Keil and Mack, 1986). Consumer services generally were found everywhere as indicated by invariant location quotients (approximately equal to one) across the four county groups.

The metropolitan/non-metropolitan pattern of location can be seen much more clearly in Table 4, which shows the service sector disaggregated to the two-digit SIC level. At this level of disaggregation, service industries appear to be poorly represented in non-metropolitan areas. Of 45 service industries, only 10 had a relatively high profile in non-metropolitan areas (location quotients greater than one), and seven of the 10 were residentially oriented. Those seven are listed below:

1. food stores,

2. auto dealerships and gas stations,

3. public utility companies,

4. state and local government offices,

5. combinations of real estate, loan, insurance, and law offices,

6. private households (maids, cooks, gardeners), and

7. hardware stores, lumber yards, and mobile 
Table 3

Employment Shares and Location Quotients for Selected Groups of Industries

Metropolitan and Non-metropolitan Areas, 1984

\begin{tabular}{|c|c|c|c|c|c|c|c|c|c|}
\hline \multirow[b]{3}{*}{$\begin{array}{l}\text { Urban Orientation } \\
\text { and Industry }\end{array}$} & \multirow[b]{3}{*}{$\begin{array}{l}\text { Share in } \\
\text { All Areas** } \\
\text { (percent) }\end{array}$} & \multicolumn{4}{|c|}{ Metropolitan Areas* } & \multicolumn{4}{|c|}{ Non-metropolitan Counties* } \\
\hline & & \multicolumn{2}{|c|}{$\begin{array}{l}\text { With Over One } \\
\text { Million People } \\
\end{array}$} & \multicolumn{2}{|c|}{$\begin{array}{c}\text { With One Million } \\
\text { or Less People }\end{array}$} & \multicolumn{2}{|c|}{$\begin{array}{c}\text { Adjacent to } \\
\text { Metropolitan Area } \\
\text { Share of }\end{array}$} & \multicolumn{2}{|c|}{$\begin{array}{l}\text { Non-adjacent to } \\
\text { Metropolitan Area }\end{array}$} \\
\hline & & $\begin{array}{l}\text { Share of } \\
\text { Employment** } \\
\text { (percent) }\end{array}$ & $\mathrm{LQ}^{* * *}$ & $\begin{array}{l}\text { Share of } \\
\text { Employment** } \\
\text { (percent) }\end{array}$ & LQ*** & $\begin{array}{l}\text { Share of } \\
\text { Employment** } \\
\text { (percent) }\end{array}$ & LQ*** & $\begin{array}{l}\text { Share of } \\
\text { Employment** } \\
\text { (percent) }\end{array}$ & $\mathrm{LQ}^{* * *}$ \\
\hline \multicolumn{10}{|l|}{ Large Urban Area-oriented } \\
\hline Producer services & 13.8 & 17.3 & 1.25 & 12.0 & 0.87 & 7.3 & 0.53 & 7.7 & 0.56 \\
\hline Urban Area-oriented & 19.3 & 21.3 & & 18.4 & & 15.1 & & 16.1 & \\
\hline Distributive services & 10.6 & 12.0 & 1.13 & 9.8 & 0.93 & 7.7 & 0.72 & 8.9 & 0.84 \\
\hline Social Services & 8.7 & 9.3 & 1.07 & 8.6 & 0.99 & 7.4 & 0.85 & 7.2 & 0.83 \\
\hline Rural Area-oriented & 44.3 & 39.4 & & 46.3 & & 55.8 & & 53.2 & \\
\hline Extractive & 2.1 & 0.8 & 0.37 & 1.9 & 0.88 & 5.4 & 2.51 & 6.8 & 3.18 \\
\hline Government & 18.7 & 16.6 & 0.89 & 20.2 & 1.08 & 21.2 & 1.13 & 22.5 & 1.20 \\
\hline Manufacturing and construction & 23.5 & 22.0 & 0.93 & 24.2 & 1.03 & 29.2 & 1.24 & 23.9 & 1.01 \\
\hline \multicolumn{10}{|l|}{ Ubiquitous } \\
\hline Consumer services & 22.5 & 22.1 & 0.98 & 23.2 & 1.03 & 21.8 & 0.97 & 22.9 & 1.02 \\
\hline Total & 100.0 & 100.0 & 0.0 & 100.0 & 0.0 & 100.0 & 0.0 & 100.0 & 0.0 \\
\hline
\end{tabular}

*Metropolitan counties are those which were in Metropolitan Statistical Areas designated by the Office of Management and Budget as of 1983. All other counties are nonmetropolitan.

** Shares may not add to exactly 100.0 due to rounding.

***Location quotients measure the representation of an industry in a specific group of counties, such as large metropolitan areas or non-adjacent, non-metropolitan

counties. Industries with LQs greater than one could be considered overrepresented in a particular group of counties and those with LQs of under one as underrepresented.

Location quotients are calculated by dividing the shares of total employment for a group of areas by the shares for the United States as a whole. For example, the LQs in

column three were obtained by dividing the numbers in column two by the numbers in column one. The LQs presented are for 1984, the most recent year covered in the

study. The pattern of LQs across the four county groups in 1984 is approximately the same as was in 1969, except for construction and manufacturing, where LQs for the

two groups of non-metropolitan counties were significantly lower in 1984 than in 1969.

Source: Compiled from county data provided by the Bureau of Economic Analysis, U.S. Department of Commerce. 
Employment Shares and Location Quotients for Selected Groups of Service-producing Industries Metropolitan and Non-metropolitan Areas, 1984

\begin{tabular}{|c|c|c|c|c|c|c|c|c|c|}
\hline \multirow[b]{2}{*}{$\begin{array}{l}\text { Urban Orientation } \\
\text { and Industry }\end{array}$} & \multirow[b]{2}{*}{$\begin{array}{l}\text { Share in } \\
\text { All Areas** } \\
\text { (percent) }\end{array}$} & \multicolumn{4}{|c|}{ Metropolitan Areas* } & \multicolumn{4}{|c|}{ Non-metropolitan Counties* } \\
\hline & & $\begin{array}{c}\text { With Over } \\
\text { Million } \mathrm{Pe} \\
\text { Share of } \\
\text { Employment** } \\
\text { (percent) }\end{array}$ & LQ*** & $\begin{array}{c}\text { With One MT } \\
\text { or Less Pec } \\
\text { Share of } \\
\text { Employment** } \\
\text { (percent) }\end{array}$ & $\mathrm{LQ}^{* * *}$ & $\begin{array}{r}\text { Adjacent } \\
\text { Metropolitar } \\
\text { Share of } \\
\text { Employment** } \\
\text { (percent) }\end{array}$ & $\begin{array}{l}0 \\
\text { Area }\end{array}$ & $\begin{array}{l}\text { Non-adjacen } \\
\text { Metropolitan } \\
\text { Share of } \\
\text { Employment** }^{*} \text { (percent) }\end{array}$ & $\begin{array}{l}\text { to } \\
\text { Area }\end{array}$ \\
\hline \multicolumn{10}{|l|}{ Large Urban Area-oriented } \\
\hline Security and commodity brokers (62) & 0.3 & 0.6 & 1.69 & 0.2 & 0.46 & 0.0 & 0.09 & 0.0 & 0.12 \\
\hline Air transportation (45) & 0.5 & 0.8 & 1.58 & 0.3 & 0.58 & 0.1 & 0.15 & 0.1 & 0.21 \\
\hline Motion pictures (78) & 0.2 & 0.3 & 1.48 & 0.1 & 0.57 & 0.1 & 0.39 & 0.1 & 0.56 \\
\hline Transportation services (47) & 0.3 & 0.4 & 1.46 & 0.2 & 0.69 & 0.1 & 0.30 & 0.1 & 0.31 \\
\hline Business services (73) & 4.0 & 5.6 & 1.39 & 3.3 & 0.81 & 1.2 & 0.30 & 1.2 & 0.29 \\
\hline Museums (84) & 0.0 & 0.1 & 1.39 & 0.0 & 0.78 & 0.0 & 0.45 & 0.0 & 0.28 \\
\hline Holding investment companies (67) & 0.1 & 0.2 & 1.38 & 0.1 & 0.81 & 0.0 & 0.33 & 0.0 & 0.33 \\
\hline Miscellaneous services (89) & 1.1 & 1.5 & 1.35 & 0.9 & 0.80 & 0.4 & 0.39 & 0.5 & 0.46 \\
\hline Legal services $(81)$ & 0.6 & 0.8 & 1.30 & 0.5 & 0.80 & 0.3 & 0.51 & 0.4 & 0.56 \\
\hline Water transportation (44) & 0.2 & 0.2 & 1.30 & 0.1 & 0.72 & 0.1 & 0.62 & 0.1 & 0.76 \\
\hline Insurance carriers (63) & 1.3 & 1.7 & 1.30 & 1.3 & 0.98 & 0.4 & 0.27 & 0.3 & 0.23 \\
\hline Real estate (65) & 1.2 & 1.5 & 1.29 & 1.0 & 0.84 & 0.6 & 0.48 & 0.6 & 0.54 \\
\hline Private educational services (82) & 1.4 & 1.7 & 1.24 & 1.2 & 0.88 & 0.9 & 0.68 & 0.6 & 0.47 \\
\hline \multicolumn{10}{|l|}{ Urban-oriented } \\
\hline Non-bank credit agencies (61) & 0.7 & 0.8 & 1.18 & 0.7 & 0.94 & 0.4 & 0.63 & 0.4 & 0.61 \\
\hline Insurance agents (64) & 0.5 & 0.6 & 1.17 & 0.5 & 0.90 & 0.4 & 0.69 & 0.4 & 0.76 \\
\hline Wholesale trade & 5.5 & 6.4 & 1.17 & 5.0 & 0.91 & 3.6 & 0.65 & 4.3 & 0.78 \\
\hline Passenger transportation (41) & 0.3 & 0.3 & 1.17 & 0.3 & 0.94 & 0.2 & 0.73 & 0.2 & 0.59 \\
\hline Communications (48) & 1.3 & 1.6 & 1.17 & 1.3 & 0.94 & 0.8 & 0.60 & 1.0 & 0.73 \\
\hline Auto repair and garages (75) & 0.7 & 0.8 & 1.14 & 0.7 & 1.00 & 0.4 & 0.62 & 0.4 & 0.65 \\
\hline Banking (60) & 1.7 & 1.9 & 1.14 & 1.4 & 0.84 & 1.5 & 0.87 & 1.6 & 0.94 \\
\hline Miscellaneous repair services (76) & 0.3 & 0.4 & 1.13 & 0.3 & 0.94 & 0.2 & 0.74 & 0.2 & 0.79 \\
\hline Apparel and accessories (56) & 1.0 & 1.1 & 1.12 & 1.0 & 0.98 & 0.7 & 0.65 & 0.8 & 0.78 \\
\hline Federal civilian govemment & 3.0 & 3.3 & 1.10 & 2.9 & 0.98 & 2.2 & 0.73 & 2.4 & 0.81 \\
\hline Personal services $(72)$ & 1.0 & 1.1 & 1.07 & 1.1 & 1.05 & 0.7 & 0.72 & 0.7 & 0.74 \\
\hline Miscellaneous retail stores (59) & 2.1 & 2.2 & 1.05 & 2.1 & 1.00 & 1.8 & 0.86 & 1.8 & 0.87 \\
\hline Fumiture and fumishings (57) & 0.7 & 0.7 & 1.05 & 0.7 & 1.04 & 0.5 & 0.76 & 0.6 & 0.85 \\
\hline Amusement services† (79) & 0.8 & 0.9 & 1.05 & 0.9 & 1.06 & 0.6 & 0.79 & 0.6 & 0.78 \\
\hline Retail; general merchandise (53) & 2.2 & 2.3 & 1.02 & 2.4 & 1.08 & 1.8 & 0.78 & 1.8 & 0.82 \\
\hline
\end{tabular}


Table 4 (Continued)

\section{Ubiquitoust†}

Social services (83)

Medical and other health services (80)

Eating and drinking places (58)

Trucking and warehousing (42)

Membership organization (86)

Federal military services

Hotels and lodging places (70)

1.2
6.1
5.4
1.3
1.6
2.7
1.3

$\begin{array}{ll}1.3 & 1.06 \\ 6.2 & 1.02 \\ 5.4 & 1.00 \\ 1.2 & 0.94 \\ 1.6 & 1.03 \\ 2.1 & 0.78 \\ 1.1 & 0.85\end{array}$

$6.2 \quad 1.03$

1.03
1.05

1.09

1.03

1.29

1.13

1.1
5.4

1.1

0.92

0.88

0.90

$1.2 \quad 0.95$

$1.2 \quad 0.77$

0.77
0.92

0.92
0.93

1.2

\section{Rural-oriented}

Food stores (54)

Auto dealerships, gas stations (55)

Electricity, gas, sanitary service (49)

\begin{tabular}{|c|c|c|c|c|c|c|c|c|}
\hline 2.6 & 2.5 & 0.93 & 2.7 & 1.03 & 3.0 & 1.15 & 2.9 & 1.11 \\
\hline 1.8 & 1.6 & 0.90 & 1.9 & 1.05 & 2.1 & 1.18 & 2.2 & 1.21 \\
\hline 0.9 & 0.8 & 0.88 & 0.9 & 1.02 & 1.2 & 1.32 & 1.1 & 1.27 \\
\hline 0.0 & 0.0 & 0.86 & 0.0 & 1.00 & 0.0 & 1.25 & 0.0 & 1.45 \\
\hline 13.1 & 11.3 & 0.86 & 3.8 & 1.06 & 16.6 & 1.26 & 16.8 & 1.29 \\
\hline 0.7 & 0.6 & 0.86 & 0.7 & 1.05 & 0.8 & 1.23 & 0.9 & 1.37 \\
\hline 0.6 & 0.4 & 0.75 & 0.6 & 1.14 & 0.8 & 1.51 & 0.7 & 1.33 \\
\hline 0.4 & 0.3 & 0.80 & 0.4 & 1.06 & 0.4 & 1.09 & 0.4 & 1.70 \\
\hline 1.7 & 1.3 & 0.74 & 1.7 & 0.97 & 3.0 & 1.78 & 2.9 & 1.68 \\
\hline 0.0 & 0.0 & 0.61 & 0.0 & 1.17 & 0.0 & 1.15 & 0.0 & 2.29 \\
\hline
\end{tabular}

Combined real estate, insurance, etc. (66)

State and local government

Building materials, etc. (52)

Agricultural services (7)

Railroad transportation (40)

Private households (88)

(40)

*,**,***See footnotes to Table 3

†Not elsewhere classified

††Includes industry groups not elsewhere classified

Source: Compiled from county data provided by the Bureau of Economic Analysis, U.S. Department of Commerce. 
home dealers.

The other three industries can be identifies as possibly providing services to export-oriented activities in nonmetropolitan areas. They are listed below:

8. agricultural service activities (crop services, fertilizer, and pest control firms),

9. railroad activities (grain and livestock terminals), and

10. gasoline and oil pipeline operations.

None of the two-digit service industries can be singled out as exporting services directly to metropolitan areas. Most service industries (28 of 45 ) were concentrated (location quotients greater than one) in metropolitan or large metropolitan areas. Highly specialized services, such as those provided by security and commodity brokers, large financial and insurance institutions, and specialized legal, accounting, and data processing firms, were found almost exclusively in large metropolitan areas. A wide range of other activities, such as banking, large department stores, and specialty retail and repair shops, also appeared to be oriented more to metropolitan than to non-metropolitan locations. Transportation service facilities and wholesale trade operations were primarily urban-oriented as well.

Restaurants, hospitals, and motels were generally found in both non-metropolitan and metropolitan areas. Their locations appear to be more ubiquitous than either the group of 28 specialized metropolitan service industries or the small group of residential non-metropolitan services.

The concentration of services in metropolitan areas seems to be a well-established fact in the United States. Our data support the theory of an urban hierarchy of services that assumes that large cities specialize in a wider range of service activities than small, non-metropolitan places. According to central place theory, we would expect large metropolitan areas to specialize in more service activities than would small, non-metropolitan areas. Thus, we would expect that as city size increases,

1. family incomes increase and consumers demand a greater variety of services (for example, more two-earner families use restaurants, day care centers, and other personal services),

2. agglomerations of corporate headquarters and other administrative facilities increasingly hire specialized business services that can be obtained at less cost than if they provided them themselves, and
3. generalized, multiservice activities (general auto repair shops, banks and stores) are taken over by more specialized, restricted lines of services such as brake repair specialists, investment counselors, specialty retail outlets, and so on.

\section{Conclusions and Policy Implications}

Two hypotheses implied by previous studies and further examined in this paper are critical to arguments concerning the role services may play in non-metropolitan development. The first is that the non-metropolitan service economy depends on traditional, basic goods production and other industries attracted by the natural amenities of non-metropolitan areas (recreation and retirement). The second hypothesis concerns the location of services; that is, services will continue to centralize in and around cities, unless changes in communications and information technologies weaken the ties of service production to major population centers and cause them to decentralize.

With regard to the first hypothesis, the data clearly show that services employment increased much faster than goods-producing employment everywhere. However, non-metropolitan service growth did not keep pace with metropolitan service growth over the 1969-84 period, and sluggish growth in goods-production since 1976 appears to be one of the factors contributing to the slowdown.

The second hypothesis, that services are generally metropolitan-oriented activities, also is supported by our data. Employment shares in most service industries increased with urbanization. Except for service industries catering to consumers (consumer services) and a few service industries linked to the traditional economic base, most service industries were not oriented to non-metropolitan areas. Thus far, we cannot document that services have loosened their ties to big cities and have begun to decentralize to non-metropolitan sites.

Based on our analysis, services are unlikely to decentralize soon to non-metropolitan areas despite the recent revolution in communications and information technology. Over the near term, it might be more realistic to continue considering non-metropolitan services as playing a "passive role" in non-metropolitan growth. Although demand for consumer services in non-metropolitan areas will continue to benefit from changes in demography, income, and tastes, overall demand will continue to depend heavily on the expansion of basic manufacturing, retirement, and recreation activities. Services should be considered in non-metropolitan development plans for traditional reasons as a part of the non-basic 
sector driven by expansion of the basic sector.

Over a longer timespan, however, non-metropolitan service employment might be linked to a long wave of development, one that parallels but always lags behind the metropolitan cycle. This process is analogous to the filtering down or life cycle process for manufactured goods wherein metropolitan manufacturing industries relocate to non-metropolitan areas to take advantage of lower labor costs after they mature and their production processes become standardized. Metropolitan industries are always in a more advanced phase, developing new technologies and applying them to meet the rapidly changing requirements of the metropolitan economy. Nonmetropolitan businesses invariably lag behind metropolitan businesses in this innovative process.

A transitional policy that lends temporary support to the non-metropolitan economy may be the best development approach. Non-metropolitan areas eventually could move into a new industrial phase similar to that of the 1960 s and early 1970s in which low-wage manufacturing shifted from metropolitan to non-metropolitan areas. Metropolitan-based corporations in the service sector could seek low-wage non-metropolitan sites, free of metropolitan congestion and abundant in non-metropolitan amenities for their auxiliary operations. Once this process begins, the dispersion could be rapid for some exportoriented service industries.

Because of continuing improvements in communications, transportation, and new information technology, metropolitan-oriented service industries that deliver information services may be able to move swiftly from an innovative phase to a mass delivery and decentralization phase. Service industries would tend to locate in major population centers during the innovative phase so they could develop and market new services, better assume necessary risks, hire the requisite professional, managerial and skilled labor, and grow rapidly. As the new industries mature, their markets would expand and they would attempt to hold wage rates down through task division by replacing the skilled jobs created during their developmental phase with less skilled jobs. This situation could mean more auxiliary service functions, outlets, and subcontractors at suburban and close-in non-metropolitan areas.

An export-based service economy cannot be created overnight. Local economies might develop by substituting local services for those previously sought outside the community while waiting for traditional goods-producing industries to recover from their current difficulties, or by building up new outside sources of income by attracting retirees or tourists.

Over the long term, telecommunications and new information technologies may make it possible for some metropolitan-oriented services to decentralize to nonmetropolitan areas. The most likely shift at this stage appears to be export-oriented business services moving to non-metropolitan areas adjacent to the major metropolitan centers where headquarters, other administrative facilities, and attendant producer services tend to agglomerate.

\section{Notes}

"The term "agglomeration" refers to the concentration of people attracted to one place because many firms are in that place. Because of the large market, firms can specialize, produce, and market goods and services at lower costs (Nourse, 1968).

${ }^{2}$ We have chosen to use metropolitan areas instead of the "rest of the world" as our standard of comparison for domestic non-metropolitan areas. We thus implicitly assume that locational choice is limited to domestic metropolitan and non-metropolitan sites. Differences between foreign, especially third world, countries and domestic non-metropolitan sites are not analyzed in this paper.

The employment location quotient compares industry share of employment at the county or multi-county level with national shares by means of a ratio. It has well-known limitations. First, it does not take into account labor productivity differences among areas. For example, a high location quotient could mean that a relatively large proportion of the total work force in an area is employed in an industry because that industry tends to use more labor relative to capital in that industry than in other areas. Second, consumption patterns vary among areas and this could result in a location quotient that does not reflect trade activity. Third, aggregation of employment into broad industry categories and county groupings conceals many activities that are almost totally exported.

\section{References}

Bender, Lloyd D. "The Role of Services in Regional Development Policies." Land Economics. 62:1 (February 1987). 62-72.

Beyers, William B., and Michael J. Alvine. "Export Services in Post-industrial Society." Papers and Proceedings of the Regional Science Association . 57 (1985). 31-45.

Blackley, Paul R. "Urban-Rural Variations in the Structure of Manufacturing Production." Urban Studies. 23:6 (December 1986). 471-83.

Cocheba, Donald J., Robert W. Gilmer, and Richard S. Mack. "Data Refinement Recommendations and Their Impact on a Study of the Tennessee Valley." Growth and Change. 16:4 (October 1985). 20-42.

- "Causes and Consequences of Slow Growth in the Tennessee Valley's Service Sector." Growth and 
Change. 17:1 (January 1986). 51-65.

Daniels, P. W. Service Industries: A Geographical Appraisal. New York: Methuen, 1985.

Duncan, Otis D. "Service Industries and the Urban Hierarchy." Regional Science Association (Proceedings). 5 (1959). 22-32.

Fuchs, Victor. The Service Economy. New York: Columbia University Press, 1968.

Gamick, Daniel H. "Shifting Balances in U.S. Metropolitan and Nonmetropolitan Area Growth." International Regional Science Review. 9:3 (1984). 257-73. "Patterns of Growth in Metropolitan and Nonmetropolitan Areas: An Update." Survey of Current Business. (May 1985). 33-38.

Keil, Stanley R., and Richard S. Mack. "Identifying Export Potential in the Service Sector." Growth and Change. 17:2 (April 1986). 1-10.

Leven, Charles L. "Regional Development Analysis and Policy." Journal of Regional Analysis. 25:4 (November 1985). 569-92.

North, Douglas C. "Location Theory and Regional Economic Growth." Journal of Political Economy. 63 (June 1955). 243-58.

Nourse, Hugh O. Regional Economics. New York: McGraw
Hill, 1968.

Noyelle, Thierry J. "The Rise of Advanced Services: Some Implications for Economic Development." Journal of the American Planning Association. 49:3 (Summer 1983). 281-90.

Polese, Mario. "Regional Demand for Business Services and Interregional Service Flows in a Small Canadian Region." Papers and Proceedings of the Regional Science Association. 50 (1982). 151-63.

Singlemann, J. From Agriculture to Services. Beverly Hills, Calif.: Sage Publications, 1979.

Smith, Stephen M. "Export Orientation of Nonmanufacturing Businesses in Nonmetropolitan Communities." American Journal of Agricultural Economics. 66:2 (May 1984). $145-55$.

, and Glen C. Pulver. "Nonmanufacturing Business as a Growth Alternative in Nonmetropolitan Areas." Journal of the Community Development Society. 12:1 (1981). 33-47.

Stanback, Thomas M. Jr. Understanding the Service Economy Employment, Productivity, Location. Baltimore, Md.: Johns Hopkins Press, 1979. and Thierry J. Noyelle. Cities in Transition. Totowa, N.J.: Allanheld Osmun and Co., 1982. 


\section{Appendix Table 1}

Classification of Industries for Employment Analysis

\begin{tabular}{|c|c|c|c|}
\hline $\begin{array}{l}\text { Industry Group and } \\
\text { Constituent Two-Digit Industry }\end{array}$ & $\begin{array}{l}\text { Two-Digit } \\
\text { SIC Code }\end{array}$ & $\begin{array}{l}\text { Industry Group and } \\
\text { Constituent Two-Digit Industry }\end{array}$ & $\begin{array}{l}\text { Two-Digit } \\
\text { SIC Code }\end{array}$ \\
\hline Extractive & & Government & \\
\hline Agriculture and forestry & $01-06$ & Federal civilian & \\
\hline Fishing and mining & 08-14 & Federal military & \\
\hline Manufacturing & 20-39 & State and local & \\
\hline Construction & $15-17$ & Producer Services & \\
\hline Consumer Services & & Agricultural services & 07 \\
\hline Building materials, etc. & 52 & Banking & 60 \\
\hline Retail general merchandise & 53 & Non-bank credit agencies & 61 \\
\hline Food stores & 54 & Security and commodity brokers & 62 \\
\hline Auto dealerships and gas stations & 55 & Insurance carriers & 63 \\
\hline Apparel and accessories & 56 & Insurance agents & 64 \\
\hline Fumiture and furnishings & 57 & Real estate & 65 \\
\hline Eating and drinking places & 58 & Combined real estate, insurance, etc. & 66 \\
\hline Miscellaneous retail stores & 59 & Holding investment companies & 67 \\
\hline Hotels and other lodging places & 70 & Miscellaneous businesses services & 73 \\
\hline Personal services & 72 & Legal services & 81 \\
\hline Auto repair service; garages & 75 & Miscellaneous services & 89 \\
\hline Miscellaneous repair services & 76 & & \\
\hline Amusement services* & 79 & Distributive Services & \\
\hline Motion pictures & 78 & Railroad transportation & 40 \\
\hline \multirow[t]{2}{*}{ Private households } & 88 & Passenger transit & 41 \\
\hline & & Trucking and warehousing & 42 \\
\hline Social Services & & Water transportation & 44 \\
\hline Medical and other health services & 80 & Transportation by air & 45 \\
\hline Private educational services & 82 & Pipeline transportation & 46 \\
\hline Social services & 83 & Transportation services & 47 \\
\hline \multirow[t]{3}{*}{ Museums } & 84 & Communications & 48 \\
\hline & & Electricity, gas, and sanitary service & 49 \\
\hline & & Wholesale trade & 50,51 \\
\hline
\end{tabular}

*Not elsewhere classified 